\title{
Bordetella trematum sp. nov., Isolated from Wounds and Ear Infections in Humans, and Reassessment of Alcaligenes denitrificans Rüger and Tan 1983
}

\author{
P. VANDAMME, ${ }^{1 *}$ M. HEYNDRICKX, ${ }^{1}$ M. VANCANNEYT, ${ }^{1}$ B. HOSTE, ${ }^{1}$ P. DE VOS, ${ }^{1}$ \\ E. FALSEN, ${ }^{2}$ K. KERSTERS, ${ }^{1}$ AND K.-H. HINZ ${ }^{3}$
}

\begin{abstract}
Laboratorium voor Microbiologie, University of Ghent, Ghent, Belgium ${ }^{1}$; Department of Clinical Bacteriology, University of Göteborg, Göteborg, Sweden ${ }^{2}$; and Klinik für Geflügel der Tierärztlichen Hochschule, Hannover, Germany ${ }^{3}$
\end{abstract}

\begin{abstract}
Ten strains recognized on the basis of a computer-assisted numerical comparison of whole-cell protein patterns as members of a novel species belonging to the family Alcaligenaceae were examined by using an integrated phenotypic and genotypic approach. This species, for which we propose the name Bordetella trematum sp. nov., was more closely related to the type species of the genus Bordetella (Bordetella pertussis) than to the type species of the genus Alcaligenes (Alcaligenes faecalis) and had the general characteristics of members of this family (i.e., a DNA base ratio in the range from 57 to $70 \mathrm{~mol} \%$, a fatty acid profile characterized by high percentages of 16:0, 17:0 cyclo, and 14:0 3OH, nonsaccharolytic metabolism, and several classical biochemical characteristics, including aerobic and microaerobic growth, catalase activity, assimilation of citrate, an absence of anaerobic growth, and an absence of acetylmethylcarbinol and indole production, gelatin liquefaction, and esculin hydrolysis). A reevaluation of the criteria used to classify Alcaligenes denitrificans Rüger and Tan 1983 and Achromobacter xylosoxidans Yabuuchi and Ohyama 1971 as subspecies of Alcaligenes xylosoxidans and additional evidence provided in recent studies revealed that, consistent with present standards, it is appropriate to consider these two taxa distinct species of the genus Alcaligenes.
\end{abstract}

Members of the genera Bordetella and Alcaligenes occur in different ecological niches. Some are strict parasites of humans, and others are detected in several hosts, including humans, or are isolated from humans, animals, and the environment $(16,18,36)$. Bordetella pertussis, the causative agent of whooping cough, and Bordetella parapertussis are the most relevant members with respect to human medicine. Bordetella bronchiseptica and Bordetella avium are respiratory pathogens in various animal hosts; the former occasionally infects humans as well (36). Bordetella holmesii and Bordetella hinzii are novel species. $B$. holmesii is isolated from human blood samples and has never been associated with the respiratory tract, while $B$. hinzii is a nonpathogenic inhabitant of the respiratory tracts of fowl which occasionally infects humans $(3,10,31)$. All Alcaligenes species (Alcaligenes xylosoxidans subsp. xylosoxidans, $\mathrm{Al}$ caligenes xylosoxidans subsp. denitrificans, Alcaligenes piechaudii, and Alcaligenes faecalis) occur in human sources other than the respiratory tract and in the environment $(16,18)$.

Several atypical or unclassified bordetellae have been deposited in our laboratory collection for further examination. In the present study, we performed an integrated genotypic and phenotypic analysis of 10 strains which represent a novel species, for which we propose the name Bordetella trematum. Using present standards for species delineation, we also evaluated the evidence used to classify Alcaligenes denitrificans Rüger and Tan 1983 and Achromobacter xylosoxidans Yabuuchi and Ohyama 1971 as subspecies of Alcaligenes xylosoxidans (16). We propose that the subspecies classification should be abandoned and that these taxa should be considered distinct species of the genus Alcaligenes (i.e., Alcaligenes xylosoxidans and $\mathrm{Al}$ caligenes denitrificans, respectively).

* Corresponding author. Mailing address: Laboratorium voor Microbiologie, K. L. Ledeganckstraat 35, B-9000 Ghent, Belgium. Phone: (32)9.264.51.13. Fax: (32)9.264.53.46. Electronic mail address: Peter.Vandamme@rug.ac.be.

\section{MATERIALS AND METHODS}

Bacterial strains and growth conditions. All of the strains studied and their sources are listed in Table 1 . Bacteriological purity was checked by plating and examining living cells by phase-contrast microscopy and Gram-stained cells. Strains were stored as lyophilized cultures.

B. pertussis strains were grown on charcoal agar (Oxoid, Basingstoke, United Kingdom) supplemented with $10 \%$ horse blood unless indicated otherwise. All other strains were grown on Trypticase soy agar (BBL, Becton Dickinson Microbiology Systems, Cockeysville, Md.) and were incubated aerobically at 36 to $37^{\circ} \mathrm{C}$ unless indicated otherwise. Representative strains of $B$. parapertussis and $B$. bronchiseptica were also grown on charcoal-blood agar to evaluate the influence of the growth medium on the whole-cell protein patterns of these bacteria.

PAGE of whole-cell proteins. Cells were incubated for $48 \mathrm{~h}$. Preparation of cellular protein extracts, polyacrylamide gel electrophoresis (PAGE), a densitometric analysis, normalization and interpolation of the protein profiles, and a numerical analysis were performed as described by Pot et al. (26) by using the GelCompar 3.1 software package (Applied Maths, Kortrijk, Belgium). The profiles were recorded and stored on a PC computer. The levels of similarity between pairs of traces were expressed by the Pearson product moment correlation coefficient converted for convenience to a percentage.

Fatty acid methyl ester analysis. After incubation for $48 \mathrm{~h}$, a loopful of well-grown cells was harvested, and fatty acid methyl esters were prepared, separated, and identified by using the Microbial Identification System (Microbial ID, Inc., Newark, Del.) as described previously (32).

Preparation of DNA. Rapid, small-scale DNA extractions for PCR analysis were performed as described by Pitcher et al. (24), with the following slight modifications. Cells grown in petri dishes containing Trypticase soy agar for $24 \mathrm{~h}$ at $37^{\circ} \mathrm{C}$ were washed with saline buffer $(0.15 \mathrm{M} \mathrm{NaCl}, 0.01 \mathrm{M}$ EDTA; pH 8.0), and the purified DNA was treated with RNase at a final concentration of 250 $\mu \mathrm{g} / \mathrm{ml}$ of TE buffer $(10 \mathrm{mM}$ Tris- $\mathrm{HCl}, 1 \mathrm{mM}$ EDTA; $\mathrm{pH} 8.0)$ for $1 \mathrm{~h}$ at $37^{\circ} \mathrm{C}$. The quality of the purified DNA was monitored by $1 \%$ (wt/vol) agarose gel electrophoresis, and the DNA preparations were quantified by determining the $A_{260}$.

Large-scale, high-molecular-weight native DNA was prepared as described previously (32).

DNA base compositions. All of the mean guanine-plus-cytosine $(\mathrm{G}+\mathrm{C})$ values were determined by the thermal denaturation method and were calculated as described by De Ley (5).

DNA-DNA hybridization experiments. Degrees of DNA-DNA binding, expressed as percentages, were determined spectrophotometrically by the initial renaturation rate method of De Ley et al. (7). Each value given below is the average of the values from at least two hybridization experiments. When this method is used, DNA binding values of $30 \%$ and less do not represent significant levels of DNA homology. The total DNA concentration was $48 \mu \mathrm{g} / \mathrm{ml}$, and the optimal renaturation temperature in $2 \times \mathrm{SSC}(1 \times \mathrm{SSC}$ is $0.15 \mathrm{M} \mathrm{NaCl}$ plus 0.015 $\mathrm{M}$ sodium citrate, $\mathrm{pH} 7$ ) was $80.5^{\circ} \mathrm{C}$.

Amplified ribosomal DNA restriction analysis (ARDRA). The 16S rRNA 
TABLE 1. Strains studied

\begin{tabular}{|c|c|c|c|c|}
\hline Strain $^{a}$ & Species & $\begin{array}{c}\text { Other } \\
\text { designation(s) }\end{array}$ & Depositor ${ }^{a, b}$ & Source \\
\hline LMG $1229^{\mathrm{T}}$ & Alcaligenes faecalis & $\begin{array}{l}\text { NCIB } 8156^{\mathrm{T}} \\
\text { CCM } 1052^{\mathrm{T}}\end{array}$ & NCIB, CCM & Unknown \\
\hline LMG 1230 & Alcaligenes faecalis & CCEB 554 & CCEB & Feces, Czechoslovakia \\
\hline LMG 3343 & Alcaligenes faecalis & NCTC 415 & NCTC & Feces \\
\hline LMG 1861 & Alcaligenes piechaudii & NCMB 1051 & Torry Research Station & Soil \\
\hline LMG $1873^{\mathrm{T}}$ & Alcaligenes piechaudii & CIP $60.75^{\mathrm{T}}$ & CIP & Pharynx \\
\hline LMG $1231^{\mathrm{T}}$ & Alcaligenes denitrificans & $\begin{array}{l}\text { ATCC } 15173^{\mathrm{T}} \\
\text { NCTC } 8582^{\mathrm{T}}\end{array}$ & ATCC, NCTC & Soil \\
\hline LMG $1863^{\mathbf{T}}$ & Alcaligenes xylosoxidans & ATCC $27061^{\mathrm{T}}$ & E. Yabuuchi & Human ear discharge, Japan \\
\hline LMG 1851 & Bordetella avium & IPDH 363-78 & & Turkey with turkey coryza, respiratory tract, Germany \\
\hline LMG $1852^{\mathrm{T}}$ & Bordetella avium & IPDH $591-77^{\mathrm{T}}$ & & Turkey, air sac exudate, Germany \\
\hline LMG 10978 & Bordetella avium & Hommez 20 & Hommez & $\begin{array}{l}\text { Trachea, broiler with slight tracheitis and polyserositis, } \\
\text { Torhout, Belgium, } 1988\end{array}$ \\
\hline & Bordetella avium & IPDH 383-78 & & Turkey, trachea, Germany \\
\hline LMG $1232^{\mathrm{T}}$ & Bordetella bronchiseptica & NCTC $452^{\mathrm{T}}$ & NCTC & Dog, lung \\
\hline LMG 14526 & Bordetella bronchiseptica & CCUG 31300 & CCUG & Human pharynx, Sweden \\
\hline LMG 3529 & Bordetella bronchiseptica & NCTC 454 & NCTC & Rabbit, blood \\
\hline & Bordetella bronchiseptica & IPDH 45-95 & & Turkey, trachea, Germany \\
\hline LMG $13501^{\mathrm{T}}$ & Bordetella hinzii & $\mathrm{TC} 58^{\mathrm{T}}$ & Blackall & Chicken trachea, Australia \\
\hline LMG 14052 & Bordetella hinzii & & Cookson & AIDS patient, United States \\
\hline LMG 15872 & Bordetella hinzii & DMMZ 1281 & Funke & Cystic fibrosis patient, Switzerland \\
\hline LMG 15047 & Bordetella holmesii & CDC G9011 & Cookson & Human blood, 80-yr-old female, United States \\
\hline LMG $15945^{\mathrm{T}}$ & Bordetella holmesii & CCUG $34073^{\mathrm{T}}$ & CCUG & Human blood, United States \\
\hline LMG 15946 & Bordetella holmesii & CCUG 34074 & CCUG & Human blood, United States \\
\hline LMG 1816 & Bordetella parapertussis & NCTC 7385 & NCTC & Unknown \\
\hline LMG $14449^{\mathrm{T}}$ & Bordetella parapertussis & $\begin{array}{l}\text { CCUG } 413^{\mathrm{T}} \\
\text { NCTC } 5952^{\mathrm{T}}\end{array}$ & CCUG, NCTC & Whooping cough \\
\hline LMG 14522 & Bordetella pertussis & CCUG 32523 & CCUG, NCTC & Human, Sweden, 1994 \\
\hline LMG $14455^{\mathrm{T}}$ & Bordetella pertussis & $\begin{array}{l}\text { CCUG } 30873^{\mathrm{T}} \\
\text { NCTC } 10739^{\mathrm{T}}\end{array}$ & CCUG & Unknown \\
\hline LMG 15140 & Bordetella pertussis & CCUG 13475 & CCUG & Whooping cough \\
\hline LMG 15141 & Bordetella pertussis & CCUG 15610 & CCUG & Whooping cough \\
\hline LMG $13506^{\mathrm{T}}$ & Bordetella trematum & $1779^{\mathrm{T}}$ & Wirsing von Konig & Chronic otitis media, human, Germany \\
\hline LMG 14446 & Bordetella trematum & CCUG 13902 & CCUG & Leg wound, 1980 \\
\hline LMG 14447 & Bordetella trematum & CCUG 13905 & CCUG & Ankle wound, 1980 \\
\hline LMG 14448 & Bordetella trematum & CCUG 31299A & CCUG & Unknown \\
\hline LMG 14523 & Bordetella trematum & CCUG 24727 & CCUG & Leg wound, United States, 1983 \\
\hline LMG 14991 & Bordetella trematum & CCUG 13903A & CCUG & Leg wound, 1980 \\
\hline LMG 14992 & Bordetella trematum & CCUG 13903B & CCUG & Leg wound, 1980 \\
\hline LMG 14993 & Bordetella trematum & CCUG 13904 & CCUG & Arm wound, 1980 \\
\hline LMG 15543 & Bordetella trematum & CCUG 14939 & CCUG & United States, 1983 \\
\hline LMG 16652 & Bordetella trematum & DMMZ 1733 & Funke & 31-yr-old male with chronic otitis media, Switzerland \\
\hline
\end{tabular}

a ATCC, American Type Culture Collection, Rockville, Md.; Blackall, P. Blackall, Queensland Department of Primary Industries, Animal Research Institute, Yeerongpilly, Queensland, Australia; CCEB, Culture Collection of Entomogenous Bacteria, Department of Insect Pathology, Institute of Entomology, Prague, Czech Republic; CCUG, Culture Collection, University of Göteborg, Department of Clinical Bacteriology, University of Göteborg, Göteborg, Sweden; CDC, Centers for Disease Control and Prevention, Atlanta, Ga.; CIP, Collection bactérienne de l'Institut Pasteur, Paris, France; DMMZ, Department of Medical Microbiology, University of Zürich, Zürich, Switzerland; Funke, G. Funke, Department of Medical Microbiology, University of Zürich, Zürich, Switzerland; Hommez, J. Hommez, Regional Veterinary Investigation Centre, Torhout, Belgium; IPDH, Institute of Poultry Disease Hannover, Hannover, Germany; LMG, Laboratorium Microbiologie Gent Culture Collection, Universiteit Gent, Ghent, Belgium; NCIB, National Collection of Industrial Bacteria, NCIMB, Ltd., Aberdeen, Scotland, United Kingdom; NCMB, National Collection of Marine Bacteria, NCIMB, Ltd., Aberdeen, Scotland, United Kingdom; NCTC, National Collection of Type Cultures, Central Public Health Laboratory, London, United Kingdom; Wirsing von Konig, C. H. Wirsing von Konig, Institute for Hygiene and Laboratory Medicine, Städtische Krankenanstalten Krefel, Krefel, Germany.

${ }^{b}$ Our isolate unless indicated otherwise.

genes were amplified by PCR in $50 \mu$ l of PCR buffer $(10 \mathrm{mM}$ Tris- $\mathrm{HCl}$ [pH 8.4], $1.5 \mathrm{mM} \mathrm{MgCl}_{2}, 50 \mathrm{mM} \mathrm{KCl}$ ) containing $10 \mathrm{nmol}$ of each deoxynucleoside triphosphate (Pharmacia Biotech Benelux, Roosendaal, The Netherlands), 20 pmol of the forward primer (5'-AGTTTGATCCTGGCTCAG-3'; positions 10 to 27 [Escherichia coli numbering]; Pharmacia), 20 pmol of the reverse primer (5'-TACCTTGTTACGACTTCACCCCA-3'; positions 1507 to 1485 ; Pharmacia), 1.25 U of EuroTaq DNA polymerase (Eurogentec, Seraing, Belgium), and $250 \mathrm{ng}$ of template DNA. A Perkin-Elmer model 9600 thermocycler was used with the following program: initial denaturation at $95^{\circ} \mathrm{C}$ for $7 \mathrm{~min}$, followed by 40 cycles consisting of denaturation at $95^{\circ} \mathrm{C}$ for $45 \mathrm{~s}$, annealing at $57^{\circ} \mathrm{C}$ for $30 \mathrm{~s}$, and extension at $72^{\circ} \mathrm{C}$ for $1 \mathrm{~min}$, and a final extension step at $72^{\circ} \mathrm{C}$ for $10 \mathrm{~min}$. The presence and yield of the PCR product (length, about $1,500 \mathrm{bp}$ ) were monitored by $1 \%(\mathrm{wt} / \mathrm{vol})$ agarose gel electrophoresis. Restriction digestion of the amplified $16 \mathrm{~S}$ ribosomal DNA was carried out for $2 \mathrm{~h}$ at the incubation temperature recommended by the manufacturer in $20-\mu$ I reaction mixtures containing $10 \mu l$ of the PCR product solution, $2 \mu \mathrm{l}$ of commercially supplied incubation buffer, and $5 \mathrm{U}$ of one of the following restriction enzymes: HaeIII (Boehringer, Mannheim, Germany), HhaI (Pharmacia), AluI (Pharmacia), TaqI, or BstUI (New England Biolabs). After $4 \mu \mathrm{l}$ of sample buffer ( $4 \mathrm{~g}$ of sucrose and $2.5 \mathrm{mg}$ of bromophenol blue in $10 \mathrm{ml}$ of TE buffer) was added, $20 \mu \mathrm{l}$ of the restriction digest was analyzed by $2 \%$ (wt/vol) Metaphor agarose (FMC BioProducts, Rockland, Maine) gel electrophoresis at $3 \mathrm{~V} / \mathrm{cm}$ for $130 \mathrm{~min}$ in $89 \mathrm{mM}$ Tris- $89 \mathrm{mM}$ boric acid- $2 \mathrm{mM}$ EDTA (TBE buffer) ( $\mathrm{pH} 8.0$ ) containing $0.5 \mu \mathrm{g}$ of ethidium bromide per $\mathrm{ml}$. After an additional 20 min of staining with $1 \mu \mathrm{g}$ of ethidium bromide per $\mathrm{ml}$ in TBE buffer and $5 \mathrm{~min}$ of destaining with $10 \mathrm{mM} \mathrm{MgCl}$, the gels were scanned under UV illumination by using the Foto/Analyst Visionary digital documentation system (Fotodyne, Hartland, Wis.) and were digitized with an IRIS video digitizer card and Colorvision software (Inside Technology, Amersfoort, The Netherlands). Normalization of the restriction patterns was performed with the GelCompar version 3.1 software package (Applied Maths) by using plasmid 
pBR322 digested with AluI (Pharmacia) as the reference. The normalized restriction patterns obtained with the five restriction enzymes for each strain were assembled into a combined profile and were analyzed by using the Dice similarity coefficient and the unweighted pair group with mathematical average clustering algorithm.

Phenotypic tests. Strains were grown on Columbia agar base (Oxoid) supplemented with $7 \%$ defibrinated sheep blood unless stated otherwise. Cells used as inocula for biochemical tests were grown for 16 to $24 \mathrm{~h}$ under aerobic or microaerobic conditions in a moist chamber. The bacteria were suspended in a $0.15 \mathrm{M} \mathrm{NaCl}$ solution $\left(\mathrm{pH} 7.0 \pm 1\right.$ ) to a concentration of about $10^{9}$ viable bacterial cells per $\mathrm{ml}$ unless indicated otherwise.

Growth was evaluated on MacConkey agar (Merck, Darmstadt, Germany), Simmons citrate agar (Oxoid), and tyrosine agar prepared as described by Lautrop (22) by using nutrient agar (Oxoid) supplemented with $0.1 \%$ DL-tyrosine (Riedel de Haen, Seelze, Germany). Each Simmons citrate agar slant was inoculated with a loopful of a dense bacterial suspension. Growth on telluritecontaining agar was examined by using MacConkey agar supplemented with 320 $\mathrm{mg}$ of potassium tellurite hydrate (Fluka Chemie, Buchs, Switzerland) per liter. In addition, agar plates containing 100 or $50 \mathrm{mg}$ of tellurite per liter were also used.

Capsules and flagella were stained as described by Möller (23) and WalcPokrzywnicki (34), respectively, by using of bacterial cells harvested from blood agar cultures after $16 \mathrm{~h}$ of incubation at $37^{\circ} \mathrm{C}$. Motility was evaluated by microscopic examination of cells grown at 25,30 , or $37^{\circ} \mathrm{C}$

Oxidase activity was tested with a freshly prepared $1 \%$ solution of $N, N^{\prime}$ dimethyl-p-phenylene monochloride (Sigma Chemical Co., St. Louis, Mo.) and with the less sensitive reagent of Gaby and Hadley (11). The oxidase activity was determined on reagent-impregnated filter paper as described by Kersters and De Ley (15). The reactions were read within $30 \mathrm{~s}$ for the Kovács reagent and within 2 min for the reagent of Gaby and Hadley. Catalase activity was tested as described by Kersters et al. (17). Urea hydrolysis was determined by using Christensen urea agar (Merck), and the tests were read daily for up to 5 days Nitrate reduction was studied in nitrate broth cultures (Merck), and indole production was determined in standard II nutrient broth (Merck) after 24 and $48 \mathrm{~h}$ of incubation at $37^{\circ} \mathrm{C}$. Alkalinization of litmus milk was tested in steamed milk containing 7\% Kubel-Tieman litmus solution (4). To examine production of acetylmethylcarbinol (Voges-Proskauer test), glucose-phosphate medium containing $0.5 \%$ peptone (peptone no. 100; Gibco BRL, Gaithersburg, Md.), $0.5 \%$ glucose, and $0.5 \% \mathrm{~K}_{2} \mathrm{HPO}_{4}(\mathrm{pH} 6.9$ ) was used. The reactions were read after 2 and 4 days of incubation by adding the reagent of Barrit (4). To study alkalinization of amides and organic salts, modified Greenwood low-peptone medium was used as described previously (31). Tetrazolium reduction was tested on D. S. T. agar (Oxoid) supplemented with $75 \mathrm{mg}$ of tetrazolium (2,2,5-triphenyltetrazolium chloride; Sigma) per liter.

The API 20NE, API $50 \mathrm{CH}$, API ZYM, API ID32 E, and rapid ID32 A microtest systems were used as recommended by the manufacturer (bioMerieux, La Balme-les-Grottes, Montalieu-Vercieu, France). All tests were repeated at least twice.

\section{RESULTS}

PAGE of whole-cell proteins. The strains examined by whole-cell protein analysis methods are listed in Fig. 1. Duplicate protein extracts were prepared to check the reproducibility of the growth conditions and the preparation of the extracts. The levels of similarity between duplicate protein patterns were at least $94 \%$ (data not shown). The protein profiles of $B$. parapertussis and $B$. bronchiseptica strains on Trypticase soy agar and charcoal-blood agar were identical (data not shown), which suggested that comparison of the protein patterns of $B$. pertussis strains grown on charcoal-blood agar with the patterns of other species grown on Trypticase soy agar was justified.

The dendrogram obtained after a numerical analysis of the whole-cell protein patterns is shown in Fig. 1. Eight stable clusters and two strains with separate positions were differentiated. Cluster I comprises all of the B. trematum strains, which cluster above a similarity level of $86.7 \%$. Clusters II, III, V, VI, VII, and VIII each comprise the reference strains of a single species (Alcaligenes faecalis, B. hinzii, B. avium, B. holmesii, B. pertussis, and Alcaligenes piechaudii, respectively), which cluster above similarity levels of $91.5,80.7,89.4,93.6,94.5$, and $91.7 \%$, respectively. Cluster IV consists of two subclusters; $B$. parapertussis strains cluster above a similarity level of $95.9 \%$, whereas $B$. bronchiseptica strains cluster above a similarity level of $93.4 \%$. The Alcaligenes xylosoxidans and Alcaligenes denitri-

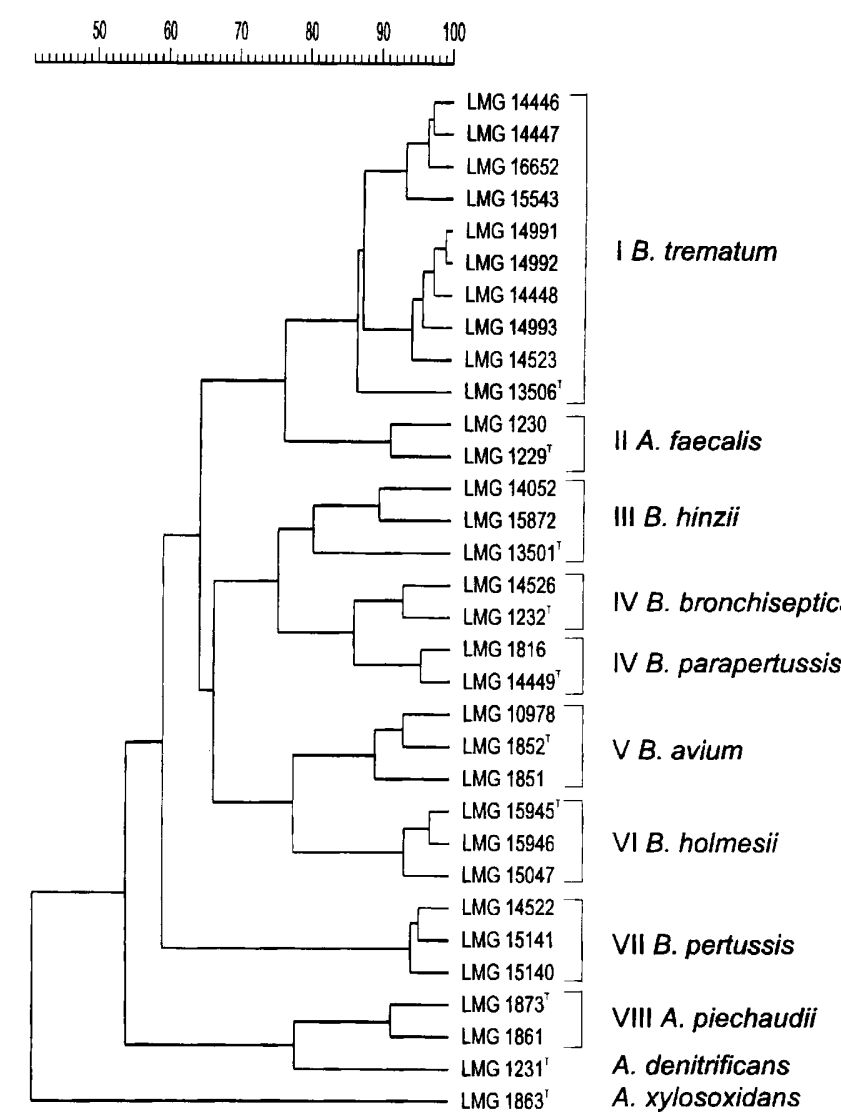

FIG. 1. Dendrogram derived from unweighed pair group average linkage of correlation coefficients for the protein patterns of all of the strains studied. The Roman numerals are cluster numbers, as discussed in the text.

ficans type strains occupy separate positions on the dendrogram.

Cellular fatty acid analysis. The average fatty acid methyl ester compositions of $B$. trematum and $B$. holmesii strains and Bordetella and Alcaligenes reference species are shown in Table 2 (data for the reference species were obtained from a previous study [31]). The major fatty acid components of the B. trematum and $B$. holmesii strains, as well as the other species, were 16:0, 17:0 cyclo, and summed feature 3. Summed feature 3 comprises two fatty acids which cannot be distinguished by the Microbial Identification System (16:1 iso I and 14:0 3OH). As discussed previously (31), in contrast to $14: 03 \mathrm{OH}$, branchedchain fatty acids have not been found previously in Bordetella or Alcaligenes strains, and therefore, the peak designated summed feature 3 probably corresponds to $14: 03 \mathrm{OH}$.

DNA base compositions. All of the DNA base ratios determined in this study are shown in Table 3. B. trematum strains have DNA base ratios between 64 and $65 \mathrm{~mol} \%$.

DNA-DNA hybridization experiments. The DNA-DNA hybridization values indicate that the $B$. trematum strains constitute a homogeneous species (the DNA binding values are $81 \%$ or more [Table 3]). No significant DNA binding values with reference strains of other Bordetella or Alcaligenes species were obtained.

ARDRA. In the numerical analysis of the combined ARDRA patterns (Fig. 2), all of the species except $B$. pertussis, $B$. parapertussis, and $B$. bronchiseptica occupied clearly distinct positions. The $B$. trematum strains clustered together at a similarity 


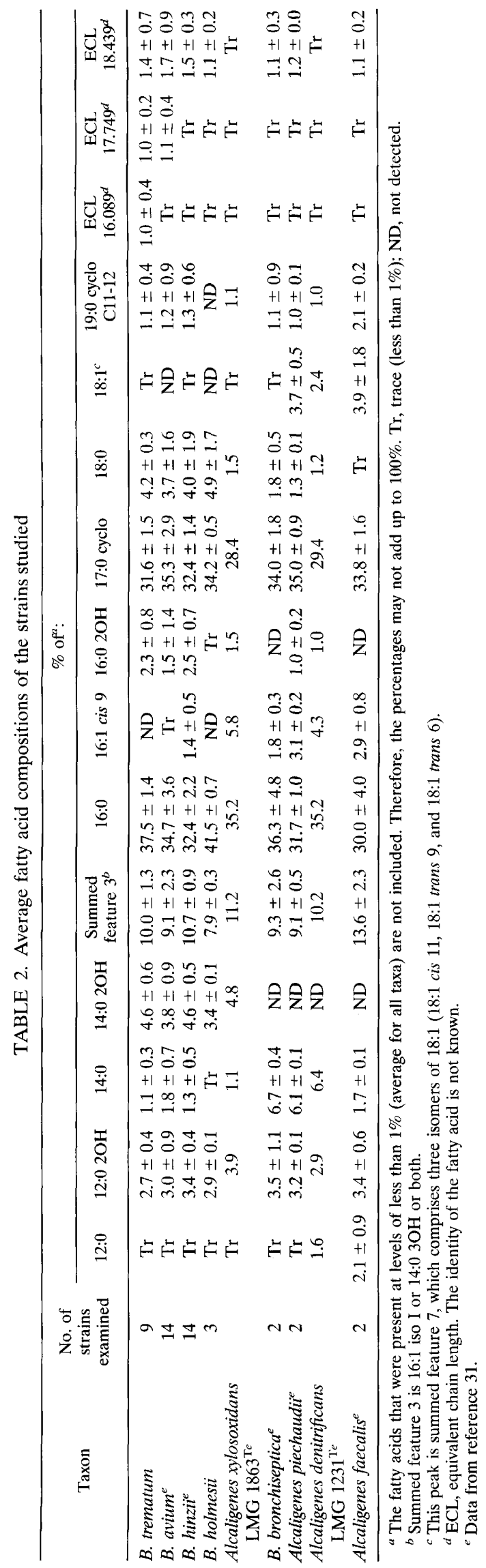

TABLE 3. DNA-DNA hybridization results and DNA base compositions of Bordetella and Alcaligenes strains

\begin{tabular}{|c|c|c|c|}
\hline \multirow[b]{2}{*}{ Strain } & \multirow{2}{*}{$\begin{array}{l}\mathrm{G}+\mathrm{C} \\
\text { content } \\
(\mathrm{mol} \%)\end{array}$} & \multicolumn{2}{|c|}{$\%$ DNA-DNA binding with: } \\
\hline & & $\begin{array}{l}\text { B. trematum } \\
\text { LMG } \\
13506^{\mathrm{T}}\end{array}$ & $\begin{array}{l}\text { B. trematum } \\
\text { LMG } 14446\end{array}$ \\
\hline $\begin{array}{l}\text { B. trematum LMG } \\
13506^{\mathrm{T}}\end{array}$ & 65 & 100 & \\
\hline B. trematum LMG 14446 & 64 & 93 & 100 \\
\hline B. trematum LMG 14993 & 64 & 93 & 81 \\
\hline B. avium LMG $1852^{\mathrm{T}}$ & 62 & 3 & \\
\hline $\begin{array}{l}\text { B. bronchiseptica LMG } \\
1232^{\mathrm{T}}\end{array}$ & 69 & 30 & \\
\hline B. hinzii $\mathrm{LMG} 13501^{\mathrm{T}}$ & 66 & 15 & \\
\hline B. holmesii LMG $15945^{\mathrm{T}}$ & 60 & & 27 \\
\hline $\begin{array}{l}\text { Alcaligenes faecalis LMG } \\
\qquad 1229^{\mathrm{T}}\end{array}$ & 57 & 9 & \\
\hline $\begin{array}{l}\text { Alcaligenes piechaudii } \\
\text { LMG } 1873^{\mathrm{T}}\end{array}$ & 65 & 20 & \\
\hline $\begin{array}{l}\text { Alcaligenes xylosoxidans } \\
\text { LMG } 1863^{\mathrm{T}}\end{array}$ & 69 & 21 & \\
\hline $\begin{array}{l}\text { Alcaligenes denitrificans } \\
\qquad \text { LMG } 1231^{\mathrm{T}}\end{array}$ & 67 & 19 & \\
\hline
\end{tabular}

level of at least $94 \%$. Within this cluster, two subgroups containing two and seven strains were recognized when restriction enzyme AluI was used. With this enzyme, the 318-bp fragment present in strains LMG 14993 and LMG 14523 was split into two smaller fragments (168 and $152 \mathrm{bp}$ ) in the other seven strains (data not shown). The B. trematum cluster was linked at a similarity level of $89 \%$ to its nearest neighbors, $B$. hinzii and $B$. avium. Differentiation of these three species was possible mainly with restriction enzyme $A l u \mathrm{I}$, although there was also a minor difference between the HaeIII patterns of $B$. trematum and $B$. hinzii (data not shown). All other species occupied more remote positions on the dendrogram (Fig. 2).

Alcaligenes faecalis occupied an isolated position on the dendrogram; all other species clustered together above a similarity level of $78 \%$. B. pertussis, B. parapertussis, and B. bronchiseptica formed a tight cluster above a similarity level of $94 \%$, and $B$. holmesii was the nearest neighbor of this cluster. The latter organism could be differentiated from the $B$. pertussis group by using restriction enzyme $A l u I$ (data not shown).

Phenotypic tests. All of the B. trematum strains except LMG 16652 and the type strains of all other species were included in the phenotypic analysis. Additional reference strains, including Alcaligenes faecalis LMG 3343, B. avium IPDH 383-78, and $B$. bronchiseptica LMG 3529 and IPDH 45-95, were used as well. Phenotypic test results are discussed below and are shown in Table 4.

The reproducibility of individual tests and microtest systems was generally excellent. However, it should be emphasized that the size of the inoculum was important for the outcome of several tests, such as alkali production from diverse substrates. Several characteristics were examined in duplicate or triplicate by using classical tests or different microtest systems or both. Production of indole was always negative (as determined by classical test and microtest systems). Urease activity was present in B. parapertussis $\mathrm{LMG} 14449^{\mathrm{T}}(\mathrm{T}=$ type strain $)$ and in $B$. bronchiseptica, findings which were obtained with both the classical test and microtest systems. A total of 22 tests (urease, arginine dihydrolase, alkaline phosphatase, leucine arylamidase, $\alpha$ - and $\beta$-galactosidase, $\alpha$-fucosidase, $\alpha$ - and $\beta$-glucosidase, $\beta$-glucuronidase, and $N$-acetyl- $\beta$-glucosamini- 


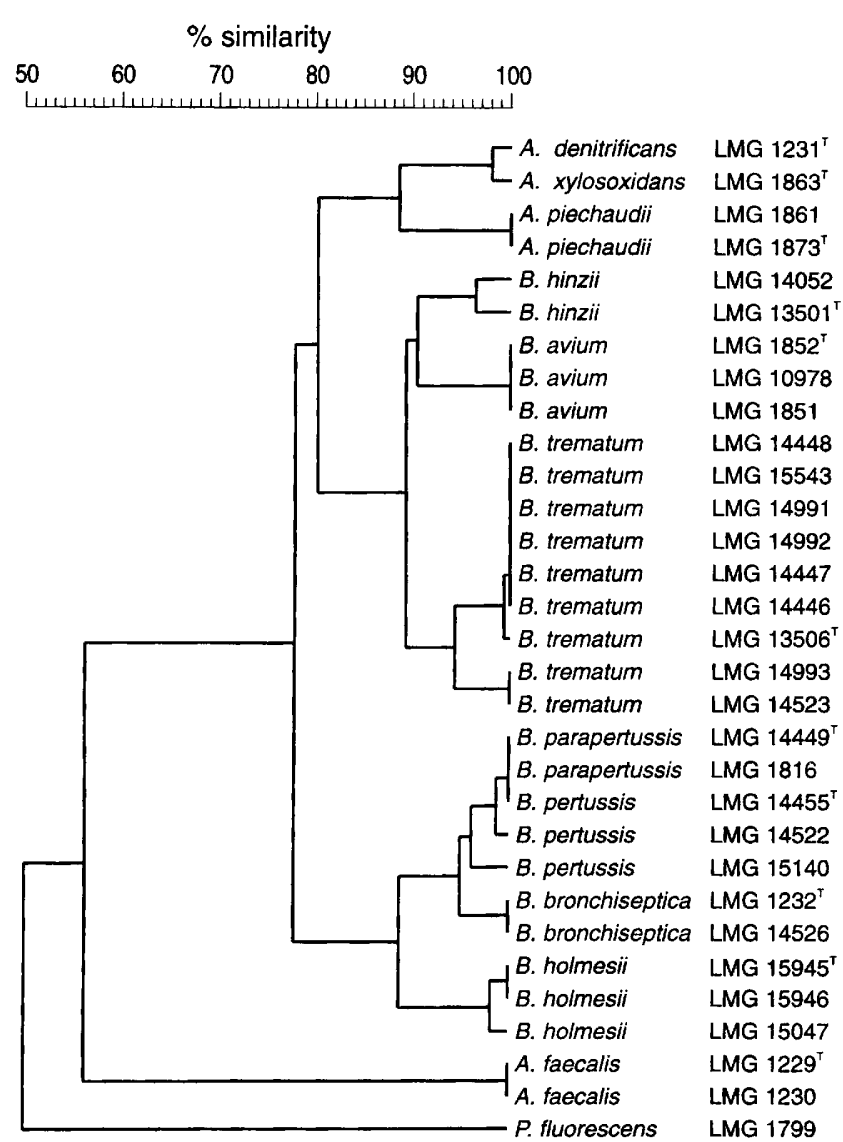

FIG. 2. Dendrogram derived from unweighed pair group average linkage of Dice similarity coefficients for the combined ARDRA patterns of all of the strains studied. Pseudomonas fluorescens LMG 1799 was used as an outgroup reference organism.

dase activities; fermentation of mannose; reduction and denitrification of nitrate; indole production; and assimilation of glucose, L-arabinose, mannose, mannitol, $\mathrm{N}$-acetylglucosamine, maltose, and gluconate) belonging to API microtest systems were present in multiple galleries. Identical test results were obtained in all analyses performed.

Different test results were obtained with different methods for nitrate reduction and alkalinization of malonate, as shown in Table 4. Several strains reproducibly assimilated esculin as determined with the API $50 \mathrm{CH}$ microtest system, but none of the strains hydrolyzed esculin when the API $20 \mathrm{NE}$ system was used.

The following characteristics were positive for all of the Bordetella and Alcaligenes strains examined: aerobic and microaerobic growth at $37^{\circ} \mathrm{C}$; aerobic growth at $30^{\circ} \mathrm{C}$; assimilation of citrate; and catalase, esterase $\mathrm{C} 4$, leucine, alanine, and glycine arylamidase, and acid phosphatase activities.

The following characteristics were negative for all of the strains examined: anaerobic growth at $37^{\circ} \mathrm{C}$; production of acetylmethylcarbinol and indole; gelatin liquefaction; esculin hydrolysis; acidification of L-arabinose, mannitol, maltose, adonitol, rhamnose, inositol, sorbitol, cellobiose, saccharose, trehalose, D- and L-arabitol, galacturonate, 5-keto-gluconate, palatinose, and glucose; assimilation of D- and L-arabinose, mannose, mannitol, $N$-acetylglucosamine, maltose, glycerol, erythritol, ribose, L-xylose, adonitol, $\beta$-methyl-D-xyloside, galactose, fructose, sorbose, rhamnose, dulcitol, inositol, sorbitol,
$\alpha$-methyl-D-mannoside, $\alpha$-methyl-D-glucoside, amygdalin, arbutin, salicin, cellobiose, lactose, melibiose, saccharose, trehalose, inulin, melezitose, raffinose, starch, glycogen, xylitol, gentiobiose, D-turanose, D-lyxose, D-tagatose, D- and L-fucose, and D- and L-arabitol; and arginine dihydrolase, ornithine decarboxylase, histidine arylamidase, $\alpha$ - and $\beta$-galactosidase, $\alpha$-fucosidase, $\alpha$ - and $\beta$-glucosidase, $\beta$-glucuronidase, $N$-acetyl- $\beta$ glucosaminidase, $\alpha$-maltosidase, 5 -bromo-indoxyl ester lipase, and $\alpha$-mannosidase activities.

All of the remaining characteristics are strain or taxon dependent and are shown in Table 4.

\section{DISCUSSION}

Taxonomic status of Alcaligenes xylosoxidans subsp. xylosoxidans and Alcaligenes xylosoxidans subsp. denitrificans. The taxonomic history of the organisms presently classified as $\mathrm{Al}$ caligenes xylosoxidans subsp. xylosoxidans and Alcaligenes $x y$ losoxidans subsp. denitrificans is complex and was reviewed in detail by Kersters and De Ley in 1984 (16). At that time, these taxa were classified as Achromobacter xylosoxidans and Alcaligenes denitrificans, respectively. DNA-DNA hybridizations between strains of these two species by the S1 endonuclease method revealed DNA-DNA binding values of 30 to $40 \%$ (19). Furthermore, the DNAs of strains belonging to the two species had indistinguishable thermal denaturation values with labeled Alcaligenes denitrificans reference rRNA (16). According to the received opinion, these taxa were classified in a single species despite phenotypic differences.

At present, a genomic species is generally considered a group of strains that exhibit about 50 to $70 \%$ DNA-DNA binding, and the differences in thermal stability between homologous and heterologous duplexes are at most 5 to $7^{\circ} \mathrm{C}(29$, $35)$. It is considered essential that phenotypic consistency supports this genotypically oriented definition $(29,35)$. The 30 to $40 \%$ DNA-DNA binding level found by Kiredjian et al. (19) is clearly below the limit of the current species standard. Phenotypic consistency would be enhanced if the two taxa were given status as different species, as they can be distinguished on the basis of phenotypic and chemotaxonomic characteristics. Finally, in the past few years, it has been demonstrated with several genera that different species may exhibit a very high level of rRNA cistron similarity, and some strains that have identical $16 \mathrm{~S}$ ribosomal DNA sequences have been shown to belong to different species (28).

In the present study, we demonstrated that strains of Alcaligenes xylosoxidans subsp. xylosoxidans and Alcaligenes xylosoxidans subsp. denitrificans can be readily differentiated by their whole-cell protein (Fig. 1) and fatty acid (Table 2) components and by other phenotypic characteristics (Table 4). DNA-DNA hybridization between the type strains of the two taxa in which the initial renaturation rate method was used revealed a level of DNA-DNA binding of only $26 \%$ (31). We believe that the previously published data conform to present standards, and the results of our analyses indicate that it is appropriate to classify these taxa as distinct species within the genus Alcaligenes. Formal nomenclatural modifications are not required as both Alcaligenes denitrificans and Alcaligenes xylosoxidans were validly described $(18,27)$. The latter name, however, should be used only for strains previously classified as Alcaligenes $x y$ losoxidans subsp. xylosoxidans (18) or Achromobacter xylosoxidans (41). The descriptions of the two species are the descriptions given by Kersters and De Ley (16) for the corresponding subspecies.

Protein electrophoretic identification of species of the family Alcaligenaceae. Previous studies revealed the efficacy of SDS- 
TABLE 4. Phenotypic characteristics of the strains examined

\begin{tabular}{|c|c|c|c|c|c|}
\hline Characteristic & $\begin{array}{l}\text { B. trematum } \\
(n=9)^{a}\end{array}$ & $\begin{array}{l}\text { B. hinzii } \\
\text { LMG } 13501^{\mathrm{T}}\end{array}$ & $\begin{array}{l}\text { B. avium } \\
(n=2)\end{array}$ & $\begin{array}{l}\text { B. bronchiseptica } \\
\qquad(n=3)\end{array}$ & $\begin{array}{l}\text { B. pertussis } \\
\text { LMG } 14455^{\mathrm{T}}\end{array}$ \\
\hline Aerobic growth at $25^{\circ} \mathrm{C}$ & $t^{b, c}$ & $+^{c}$ & $+^{c}$ & $+^{c}$ & - \\
\hline Aerobic growth at $42^{\circ} \mathrm{C}$ & + & + & $+^{c}$ & $+^{c}$ & - \\
\hline \multicolumn{6}{|l|}{ Growth on: } \\
\hline MacConkey agar & + & + & + & + & - \\
\hline $\begin{array}{l}\text { MacConkey agar containing } 320 \\
\text { mg of tellurite per liter }\end{array}$ & - & - & - & - & ND \\
\hline Simmons citrate agar & - & + & - & + & - \\
\hline Motility & + & + & + & + & - \\
\hline Diffusible brown pigment & - & - & - & - & ND \\
\hline Pigment produced from tyrosine & - & - & - & - & ND \\
\hline \multicolumn{6}{|l|}{ Oxidase activity } \\
\hline Kovács reagent & - & + & + & + & + \\
\hline Gaby-Hadley reagent & - & + & - & + & $+^{c}$ \\
\hline \multicolumn{6}{|l|}{ Nitrate reduction (classical method) } \\
\hline Formation of nitrite & $\mathrm{V}(6)^{c, d}$ & - & - & $\mathrm{V}$ & - \\
\hline Denitrification & V (1) & - & - & V & - \\
\hline \multicolumn{6}{|l|}{ Nitrate reduction (API 20NE test) } \\
\hline Formation of nitrite & $V(6)$ & - & - & + & - \\
\hline Denitrification & - & - & - & - & - \\
\hline Urease activity & - & - & - & + & - \\
\hline Lysine decarboxylase activity & - & - & - & - & - \\
\hline Tetrazolium reduction & + & + & + & + & ND \\
\hline Alkalinization of litmus milk & $-(1)^{c}$ & - & - & + & ND \\
\hline \multicolumn{6}{|l|}{ Alkali production from: } \\
\hline Acetamide & $\mathrm{V}(8)^{c, f}$ & + & $+^{f}$ & - & ND \\
\hline Adipate & + & + & $+^{f}$ & + & ND \\
\hline Glycine & - & $+^{c}$ & - & + & ND \\
\hline Propionamide & + & + & $+^{c}$ & + & ND \\
\hline Valerate & $\mathrm{V}(8)^{c}$ & + & - & $+^{c}$ & ND \\
\hline Malonamide & + & + & - & $+^{c}$ & ND \\
\hline Malonate & + & + & - & $t^{c}$ & ND \\
\hline Malonate (API ID32 E test) & - & - & - & - & - \\
\hline Glucose fermentation & - & - & - & - & - \\
\hline \multicolumn{6}{|l|}{ Assimilation of: } \\
\hline D-Glucose & - & - & - & - & - \\
\hline D-Xylose & - & - & - & - & - \\
\hline D-Gluconate & - & - & - & - & - \\
\hline Caprate & - & $+^{c}$ & - & $\mathrm{V}$ & - \\
\hline Adipate & + & + & $+^{c}$ & $+^{c}$ & - \\
\hline L-Malate & + & + & $+^{c}$ & $\mathrm{~V}$ & - \\
\hline Phenylacetate & + & + & + & + & - \\
\hline Esculin & + & + & - & - & - \\
\hline 5-Keto-gluconate & $\mathrm{V}(7)$ & - & - & - & - \\
\hline Browning on 2-keto-gluconate & - & + & - & - & - \\
\hline Alkaline phosphatase activity & $+^{c}$ & + & V & $\mathrm{V}$ & - \\
\hline Ester C8 lipase activity & $+^{c}$ & $+^{c}$ & V & V & + \\
\hline Lipase C14 activity & $\mathrm{V}(1)^{c}$ & - & - & - & - \\
\hline Trypsin activity & - & - & - & - & - \\
\hline Chymotrypsin activity & $\mathrm{V}(1)$ & - & V & - & + \\
\hline $\begin{array}{l}\text { Naphthol-AS-B1-phosphohydrolase } \\
\text { activity }\end{array}$ & $+^{c}$ & $+^{c}$ & - & - & $+^{c}$ \\
\hline \multicolumn{6}{|l|}{ Arylamidase activity with: } \\
\hline Valine & $+^{c}$ & $+^{c}$ & $\mathrm{~V}$ & - & - \\
\hline Cystine & - & - & - & - & - \\
\hline Arginine & $\mathrm{V}(2)$ & + & $\mathrm{V}$ & + & + \\
\hline Proline & - & - & - & - & ND \\
\hline Leucyl glycine & + & + & + & + & + \\
\hline Phenylalanine & $V(5)$ & - & + & - & + \\
\hline Pyroglutamic acid & - & - & - & - & - \\
\hline Tyrosine & $V(8)$ & + & + & + & + \\
\hline Glutamyl glutamic acid & $\mathrm{V}(1)$ & - & - & - & + \\
\hline Serine & + & + & + & + & + \\
\hline L-Aspartic acid & $+^{c}$ & + & $+^{c}$ & + & $+^{c}$ \\
\hline
\end{tabular}

${ }^{a} n$ is the number of strains studied.

${ }^{b}+$, positive; -, negative; $\mathrm{V}$, reaction is strain dependent; ND, not determined.

${ }^{c}$ Some strains may exhibit a weak reaction.

${ }^{d}$ The numbers in parentheses are the numbers of strains that exhibit a positive reaction.

e No growth occurs.

${ }^{f}$ Strains exhibit a positive reaction only if a heavy inoculum is used. 
TABLE 4-Continued

\begin{tabular}{|c|c|c|c|c|c|}
\hline $\begin{array}{l}\text { B. parapertussis } \\
\text { LMG } 14449^{\mathrm{T}}\end{array}$ & $\begin{array}{l}\text { B. holmesii } \\
\text { LMG } 15945^{\mathrm{T}}\end{array}$ & $\begin{array}{l}\text { Alcaligenes denitrificans } \\
\text { LMG } 1231^{\mathrm{T}}\end{array}$ & $\begin{array}{c}\text { Alcaligenes xylosoxydans } \\
\text { LMG } 1863^{\mathrm{T}}\end{array}$ & $\begin{array}{l}\text { Alcaligenes piechaudii } \\
\text { LMG } 1873^{\mathrm{T}}\end{array}$ & $\begin{array}{l}\text { Alcaligenes faecalis } \\
\qquad(n=2)\end{array}$ \\
\hline- & - & $+^{c}$ & $t^{c}$ & + & $t^{c}$ \\
\hline- & - & - & $+^{c}$ & - & $+^{c}$ \\
\hline+ & - & + & + & + & + \\
\hline$t^{c}$ & - & $+^{c}$ & - & - & - \\
\hline- & - & + & + & + & + \\
\hline- & - & + & + & + & + \\
\hline$t^{c}$ & $+^{c}$ & - & - & - & - \\
\hline+ & + & - & - & - & - \\
\hline- & - & + & + & + & + \\
\hline- & - & + & + & + & + \\
\hline- & - & + & + & + & - \\
\hline- & - & + & + & - & - \\
\hline- & - & + & - & + & - \\
\hline- & - & - & + & - & - \\
\hline+ & - & - & - & - & - \\
\hline- & - & + & + & - & - \\
\hline+ & $-^{e}$ & + & + & + & + \\
\hline- & - & + & + & - & V \\
\hline- & - & + & + & + & + \\
\hline- & - & + & + & + & - \\
\hline- & - & + & + & + & + \\
\hline- & - & + & + & + & + \\
\hline- & - & + & + & + & V \\
\hline- & - & + & + & + & $+^{c}$ \\
\hline- & - & + & $+^{c}$ & + & + \\
\hline- & - & - & - & - & + \\
\hline- & - & - & $+^{c}$ & - & - \\
\hline- & - & - & + & - & - \\
\hline- & - & - & + & - & - \\
\hline- & - & - & + & + & - \\
\hline- & - & $+^{c}$ & $+^{c}$ & - & + \\
\hline- & - & + & $+^{c}$ & + & - \\
\hline- & - & + & + & + & + \\
\hline- & - & + & + & + & V \\
\hline- & - & + & $+^{c}$ & $+^{c}$ & + \\
\hline- & - & - & - & - & - \\
\hline- & - & - & - & - & - \\
\hline- & $+^{c}$ & + & + & + & + \\
\hline+ & + & + & + & $+^{c}$ & + \\
\hline- & - & - & - & - & - \\
\hline- & - & - & - & - & V \\
\hline+ & + & - & - & - & V \\
\hline- & $+^{c}$ & $+^{c}$ & $+^{c}$ & $+^{c}$ & $+^{c}$ \\
\hline- & - & $+^{c}$ & $+^{c}$ & $+^{c}$ & $+^{c}$ \\
\hline- & - & - & - & - & V \\
\hline- & + & + & + & + & + \\
\hline- & + & + & + & - & - \\
\hline- & + & + & + & - & + \\
\hline- & - & + & + & + & - \\
\hline- & - & + & + & + & - \\
\hline- & - & + & + & + & + \\
\hline- & - & - & - & - & - \\
\hline- & - & + & + & + & + \\
\hline+ & - & + & + & + & $+^{c}$ \\
\hline
\end{tabular}

PAGE of whole-cell proteins and computer-assisted numerical comparisons of the protein electrophoretic traces for delineating species of the family Alcaligenaceae $(30,31)$. Strain LMG $13506^{\mathrm{T}}$ was previously described as a member of this family, although it did not belong to one of the established nomenspecies $(9,31)$. A protein electrophoretic analysis of various atypical Bordetella-like strains that were mainly isolated from infected wounds (Table 1) revealed substantial similarity 
between nine isolates and strain LMG $13506^{\mathrm{T}}$ (Fig. 1, cluster I). The numerical analysis revealed that all 10 of these strains had very similar protein patterns, which were distinct from the patterns of other Bordetella and Alcaligenes species, including $B$. holmesii. DNA-DNA hybridization data confirmed that the cluster I strains formed a genotypically homogeneous species (DNA-DNA binding values, $>80 \%$ ), while the DNA binding values with $B$. holmesii or representative strains of the other members of these genera were low or insignificant (Table 3).

Taxonomic position of $B$. trematum. The taxonomic position of strain LMG $13506^{\mathrm{T}}$ was determined by DNA-rRNA hybridization experiments, which revealed that this organism belonged to the family Alcaligenaceae (31). Strain LMG $13506^{\mathrm{T}}$ is genotypically, phenotypically, and chemotaxonomically representative of its group and was chosen as the type strain of a new species, for which we propose the name $B$. trematum (see below). Conclusions concerning the phylogenetic affiliation of this strain are therefore valid for the entire species.

The levels of DNA-rRNA hybridization obtained with labeled rRNAs of the type strains of various Bordetella and Alcaligenes species and the results of an ARDRA in which five different restriction enzymes were used revealed that $B$. trematum was more closely related to the type species of the genus Bordetella (B. pertussis) than to the type species of the genus Alcaligenes (Alcaligenes faecalis) (31) (Fig. 2). Thus, this new species genotypically belongs to the genus Bordetella. Phenotypically, the genera Bordetella and Alcaligenes are difficult to differentiate. Hybridization between rRNA and genomic DNA first revealed the close relationship between the two genera $(8$, $16)$, and this was later confirmed by the results of a sequence analysis of $16 \mathrm{~S}$ rRNAs $(2,38)$. These two genera constitute the family Alcaligenaceae, which belongs to the beta subclass of the Proteobacteria (6). When the descriptions of the two genera in Bergey's Manual of Systematic Bacteriology and the descriptions of the species named after publication of Bergey's Manual (18, 31,38 ) are compared, it is obvious that phenotypic differentiation at the genus level is virtually impossible. Traditionally, Bordetella species are known as respiratory tract parasites, whereas Alcaligenes species are considered primarily inhabitants of soil and water $(16,25)$. However, insights into the phylogeny of these bacteria and the recent emergence of additional species have blurred this picture. The majority of the Alcaligenes species have been shown to be only remotely related to Alcaligenes faecalis, the type species of the genus (16), and have been gradually reclassified in new genera, such as the genera Deleya (1) and Variovorax (39). The remaining genuine Alcaligenes species, Alcaligenes faecalis, Alcaligenes xylosoxidans, Alcaligenes denitrificans, and Alcaligenes piechaudii, all occur in environmental and human sources $(16,18)$. On the other hand, Bordetella species can no longer be considered strict respiratory pathogens. Indeed, $B$. trematum has never been associated with the respiratory systems of humans or animals (38), while the available data indicate that $B$. hinzii is an innocent colonizer of the respiratory tracts of poultry (31). In addition to the human $B$. hinzii isolates described previously $(3,31)$, three additional isolates were identified recently, including two strains that chronically colonized a cystic fibrosis patient (10) and a strain obtained from an endotracheal aspirate of a farmer (data for the latter strain pointed toward colonization, not infection) (33).

As mentioned previously, Alcaligenes xylosoxidans, Alcaligenes denitrificans, and Alcaligenes piechaudii are genotypically more closely related to the type species of the genus Bordetella than to the type species of the genus Alcaligenes $(2,8,38)$. Their DNA base ratios are also within the range of values obtained for Bordetella species (63 to $70 \mathrm{~mol} \%$ ), while the
DNA base ratio of Alcaligenes faecalis (55 to $60 \mathrm{~mol} \%$ ) is significantly lower (8). Reclassification of Alcaligenes xylosoxidans, Alcaligenes denitrificans, and Alcaligenes piechaudii in the genus Bordetella would enhance the genotypic homogeneity and boundaries of both genera. In the present classification, genus level differentiation by phenotypic characteristics is not possible; however, this would not be achieved by the reclassification of Alcaligenes species as suggested above. Such a reclassification would also not serve practical purposes, and therefore we do not propose nomenclatural modifications.

Differentiation of $B$. trematum from allied species. As explained above, we originally recognized strains as members of $B$. trematum on the basis of the results of SDS-PAGE of wholecell proteins. An extensive phenotypic comparison of $B$. trematum and the type and reference strains of other species revealed several differential characteristics for each of the taxa examined, as shown in Table 4. A number of discrepancies between our results and other data were noted. Our results for tetrazolium reduction and growth on tellurite-containing agar plates for the B. bronchiseptica and Alcaligenes strains did not correspond to the results of Johnson and Sneath (14). No growth was observed even when the tellurite concentration was reduced to 100 or $50 \mathrm{mg} /$ liter. In light of these results, it seems doubtful that these tests can be used for characterization of these species. Also, B. holmesii LMG $15945^{\mathrm{T}}$ did not grow on MacConkey agar, even after incubation for up to 5 days, while Weyant et al. (38) reported that most $B$. holmesii strains grew after 2 days of incubation and that all strains grew after 7 days of incubation. In contrast to data reported previously (31), in the present study Alcaligenes faecalis strains produced alkali from acetamide. However, it should be noted that the results of the alkali production test on Greenwoods low-peptone medium depend on the size of the inoculum used. Likewise, in contrast to the data in Table 4, all of the strains examined alkalinized Simmons citrate agar if heavy inocula were used (data not shown).

In the present phenotypic analysis, we included one or a few reference strains for each taxon, yet most of the data shown in Table 4 agree (see above) with previously published data which were obtained with larger numbers of strains $(16-18,25,31$, 38 ). Among the tests listed in Table 4, both oxidase tests, the urease test, and the test for growth on Simmons citrate agar are particularly useful as first screening tests.

Cellular fatty acid analysis is often used to identify and differentiate bacteria (37). We compared the fatty acid profiles of $B$. trematum and B. holmesii strains with the profiles of the other species examined previously (31). From the data in Table 2 , we deduced that cellular fatty acid analysis can be used to differentiate some species belonging to the Bordetella-Alcaligenes group. The fatty acid 14:0 $2 \mathrm{OH}$ is useful for separating two main clusters of species, a cluster containing $B$. trematum, $B$. avium, B. hinzii, B. holmesii, and Alcaligenes xylosoxidans on the one hand, and a cluster containing B. bronchiseptica, Alcaligenes piechaudii, Alcaligenes denitrificans, and Alcaligenes faecalis on the other hand. Within the first cluster, Alcaligenes xylosoxidans can be easily differentiated from the other species by using the ratio of $16: 1$ cis 9 to $17: 0$ cyclo. Only $16: 0$ has additional discriminatory power for some species of this first cluster. As demonstrated by Cookson et al. (3) and Funke et al. (10), a shorter incubation time ( 24 versus $48 \mathrm{~h}$ ) resulted in a very different ratio of $16: 1 \mathrm{cis} 9$ to $17: 0$ cyclo, which allowed clear differentiation of $B$. avium and $B$. hinzii (16:1 cis 9 is a precursor of 17:0 cyclo and therefore is present at higher levels in younger cells). Within the second cluster, Alcaligenes faecalis can be differentiated from the other species by its low level of 14:0. The percentage of $18: 1$ and the ratio of $16: 1$ cis 9 to $17: 0$ 
cyclo seem to be useful for differentiating $B$. bronchiseptica, Alcaligenes piechaudii, and Alcaligenes denitrificans, but a larger number of strains must be examined to conclude that these features have diagnostic value.

ARDRA has been used to differentiate species belonging to different genera (12), including the genera Capnocytophaga (40), Streptococcus (13), and Rhizobium (21). In the present analysis, we included nine $B$. trematum strains and reference strains of all other Bordetella and Alcaligenes species. The ARDRA patterns obtained with five different restriction enzymes were combined and used in a numerical comparison analysis (Fig. 2). B. trematum strains formed a single cluster that was clearly distinct from the other species examined. The subdivision of the $B$. trematum strains into two clusters on the basis of restriction enzyme AluI data was, to our knowledge, not supported by other genotypic or phenotypic characteristics, and strains belonging to both subclusters exhibited high levels of DNA-DNA binding with the type strain, LMG 13506 (Table 3). All other species except B. pertussis, B. parapertussis, and B. bronchiseptica are clearly separated on the dendrogram, indicating that this method is very useful for species differentiation in the family Alcaligenaceae. In view of the high levels of genotypic relatedness of $B$. pertussis, B. parapertussis, and $B$. bronchiseptica, as deduced from DNA-DNA hybridization studies $(20,31)$, it is not surprising that these species form a single cluster. When the topology of the dendrogram based on five ARDRA patterns is compared with the topology of a dendrogram based on direct $16 \mathrm{~S}$ rRNA sequencing data, it is noteworthy that both dendrograms indicate that Alcaligenes faecalis is the most remote member of the group and that the other Bordetella and Alcaligenes species are closely intertwined (38) (Fig. 2).

Description of Bordetella trematum sp. nov. Bordetella trematum (tre.ma'tum. Gr. neut. n. trema, referring to something pierced or penetrated, an aperture, or a gap; N. L. gen. pl. n. trematum, pertaining to penetrated or open things, referring to the presence of these bacteria in wounds and other exposed parts of the human body). B. trematum cells are gram-negative, non-spore-forming, capsulated rods that are motile by means of peritrichous flagella. Motility does not differ significantly when cells are grown at 25,30 , or $37^{\circ} \mathrm{C}$. In 16- to 24 -h-old cultures on blood agar, the average cell is 0.5 to $0.6 \mu \mathrm{m}$ wide and 1 to $1.8 \mu \mathrm{m}$ long; the longest rods are up to $2.4 \mu \mathrm{m}$ long. Strains produce convex, circular, and greyish cream white colonies with entire edges on blood agar. The strains do not require special growth factors and grow on conventional media. Growth is not inhibited at an incubation temperature of $42^{\circ} \mathrm{C}$, but is reduced markedly at $25^{\circ} \mathrm{C}$. Strains grow microaerobically, but not anaerobically. Colonies grown for 16 to $24 \mathrm{~h}$ on transparent D. S. T. agar at $37^{\circ} \mathrm{C}$ exhibit greenish yellow to yellow-red iridescence in obliquely transmitted light under a stereomicroscope. Other biochemical characteristics are described above and in Table 4.

The major fatty acid components of all of the strains examined are 12:0 2OH (about 3\%), 14:0 2OH (about 5\%), 16:0 (about 37\%), 17:0 cyclo (about 32\%), 16:0 2OH (about 2\%), 18:0 (about 4\%), and summed feature 3 (probably 14:0 3OH) (about 10\%).

Strains have been isolated from ear infections and wounds of humans, but not from respiratory systems. Pathogenic significance is unknown.

The DNA base composition is between 64 and $65 \mathrm{~mol} \%$ $\mathrm{G}+\mathrm{C}$. The type strain is strain LMG 13506, which was isolated from a chronic ear infection in Germany. Its $\mathrm{G}+\mathrm{C}$ content is $65 \mathrm{~mol} \%$.
All B. trematum strains have been deposited in the Laboratorium Microbiologie Gent Culture Collection.

\section{ACKNOWLEDGMENTS}

We thank Urbain Torck, Dirk Dewettinck, and Rita Leise for excellent technical assistance and all depositors of strains listed in Table 1.

P.V. and M.H. are indebted to the National Fund for Scientific Research (Belgium) for positions as postdoctoral research fellows. K.K. is indebted to the Fund for Medical Scientific Research, Belgium, for research and personnel grants. Part of this study was performed in the framework of CEC BRIDGE project BIO2-CT94-3098.

\section{REFERENCES}

1. Baumann, L., R. D. Bowditch, and P. Baumann. 1983. Description of Deleya gen. nov. created to accommodate the marine species Alcaligenes aestus, $A$. pacificus, A. cupidus, A. venustus, and Pseudomonas marina. Int. J. Syst. Bacteriol. 33:793-802.

2. Bleumink-Pluym, N. M. C., L. van Dijk, A. H. M. van Vliet, J. W. B. van der Giessen, and B. A. M. van der Zeijst. 1993. Phylogenetic position of Taylorella equigenitalis determined by analysis of amplified 16S ribosomal DNA sequences. Int. J. Syst. Bacteriol. 43:618-621.

3. Cookson, B. T., P. Vandamme, L. C. Carison, A. M. Larson, J. V. L. Sheffield, K. Kersters, and D. H. Spach. 1994. Bacteremia caused by a novel Bordetella species, "B. hinzii." J. Clin. Microbiol. 32:2569-2571.

4. Cowan, S. T. 1974. Cowan and Steel's manual for the identification of medical bacteria, 2nd ed. Cambridge University Press, Cambridge.

5. De Ley, J. 1970. Reexamination of the association between melting point, buoyant density, and chemical base composition of deoxyribonucleic acid. J. Bacteriol. 101:738-754.

6. De Ley, J. 1992. The Proteobacteria: ribosomal RNA cistron similarities and bacterial taxonomy, p. 2111-2140. In A. Balows, H. G. Trüper, M. Dworkin, W. Harder, and K.-H. Schleifer (ed.), The prokaryotes, 2nd ed., vol. 2. Springer-Verlag, Berlin.

7. De Ley, J., H. Cattoir, and A. Reynaerts. 1970. The quantitative measurement of DNA hybridization from renaturation rates. Eur. J. Biochem. 12: 133-142.

8. De Ley, J., P. Segers, K. Kersters, W. Mannheim, and A. Lievens. 1986. Intra- and intergeneric similarities of the Bordetella ribosomal ribonucleic acid cistrons: proposal for a new family, Alcaligenaceae. Int. J. Syst. Bacteriol. 36:405-414.

9. Dorittke, C., P. Vandamme, K. H. Hinz, E. M. Schemken-Birk, and C. H. Wirsing von König. 1995. Isolation of a Bordetella avium-like organism from a human specimen. Eur. J. Clin. Microbiol. Infect. Dis. 14:451-454.

10. Funke, G., T. Hess, A. von Graevenitz, and P. Vandamme. 1996. Characteristics of Bordetella hinzii strains isolated from a cystic fibrosis patient over a 3-year period. J. Clin. Microbiol. 34:966-969.

11. Gaby, W. L., and C. Hadley. 1957. Practical laboratory test for the identification of Pseudomonas aeruginosa. J. Bacteriol. 74:356-358.

12. Gürtler, V., and V. A. Stanisich. 1996. New approaches to typing and identification of bacteria using the $16 \mathrm{~S}-23 \mathrm{~S}$ rDNA spacer region. Microbiology 142:3-16.

13. Jayaro, B. M., J. J. E. Doré, Jr., G. A. Baumbach, K. R. Matthews, and S. P. Oliver. 1991. Differentiation of Streptococcus uberis from Streptococcus parauberis by polymerase chain reaction and restriction fragment length polymorphism analysis of 16 S ribosomal DNA. J. Clin. Microbiol. 29:2774 2778 .

14. Johnson, R., and P. H. A. Sneath. 1973. Taxonomy of Bordetella and related organisms of the families Achromobacteraceae, Brucellaceae, and Neisseriaceae. Int. J. Syst. Bacteriol. 23:381-404.

15. Kersters, K., and J. De Ley. 1971. Enzymatic tests with resting cells and cell-free extracts. Methods Microbiol. 5A:33-52.

16. Kersters, K., and J. De Ley. 1984. Genus Alcaligenes Castellani and Chalmers $1919,936^{\text {AL }}$, p. 361-373. In N. R. Krieg and J. G. Holt (ed.), Bergey's manual of systematic bacteriology, vol. 1. The Williams \& Wilkins Co., Baltimore.

17. Kersters, K., K.-H. Hinz, A. Hertle, P. Segers, A. Lievens, O. Siegmann, and J. De Ley. 1984. Bordetella avium sp. nov., isolated from the respiratory tracts of turkeys and other birds. Int. J. Syst. Bacteriol. 34:56-70.

18. Kiredjian, M., B. Holmes, K. Kersters, I. Guilvout, and J. De Ley. 1986. Alcaligenes piechaudii, a new species from human clinical specimens and the environment. Int. J. Syst. Bacteriol. 36:282-287.

19. Kiredjian, M., M. Popoff, C. Coynault, M. Lefêvre, and M. Lemelin. 1981. Taxonomie du genre Alcaligenes. Ann. Inst. Pasteur Microbiol. 132B:337374.

20. Kloos, W. E., N. Mohapatra, W. Dobrogosz, J. W. Ezzell, and C. R. Manclark. 1981. Deoxyribonucleotide sequence relationships among Bordetella species. Int. J. Syst. Bacteriol. 31:173-176.

21. Laguerre, G., M.-R. Allard, F. Revoy, and N. Amarger. 1994. Rapid identi- 
fication of rhizobia by restriction fragment length polymorphism analysis of PCR-amplified 16S rRNA genes. Appl. Environ. Microbiol, 60:56-63.

22. Lautrop, H. 1960. Laboratory diagnosis of whooping cough or Bordetella infections. Bull. W. H. O. 23:15-31.

23. Möller, O. 1951. A new method for staining bacterial capsules. Acta Pathol. Microbiol. Scand. 28:127-131.

24. Pitcher, D. G., N. A. Saunders, and R. J. Owen. 1989. Rapid extraction of bacterial genomic DNA with guanidium thiocyanate. Lett. Appl. Microbiol. 8:151-156

25. Pittman, M. 1984. Genus Bordetella Moreno-Lopez 1952, $178^{\text {AL }}$, p. 388-394 In N. R. Krieg and J. G. Holt (ed.), Bergey's manual of systematic bacteriology, vol. 1. The Williams \& Wilkins Co., Baltimore.

26. Pot, B., P. Vandamme, and K. Kersters. 1994. Analysis of electrophoretic whole-organism protein fingerprinting, p. 493-521. In M. Goodfellow and A. G. O'Donnell (ed.), Modern microbial methods. Chemical methods in bacterial systematics. J. Wiley and Sons, Chichester, United Kingdom.

27. Rüger, H.-J., and T. L. Tan. 1983. Separation of Alcaligenes denitrificans sp. nov., nom. rev. from Alcaligenes faecalis on the basis of DNA base composition, DNA homology, and nitrate reduction. Int. J. Syst. Bacteriol. 33:8589.

28. Stackebrandt, E., and B. M. Goebel. 1994. Taxonomic note: a place for DNA-DNA reassociation and 16S rRNA sequence analysis in the present species definition in bacteriology. Int. J. Syst. Bacteriol. 44:846-849.

29. Ursing, J. B., R. A. Rossello-Mora, E. Garcia-Valdes, and J. Lalucat. 1995. Taxonomic note: a pragmatic approach to the nomenclature of phenotypically similar genomic groups. Int. J. Syst. Bacteriol. 45:604.

30. Vancanneyt, M., P. Vandamme, and K. Kersters. 1995. Differentiation of Bordetella pertussis, B. parapertussis, and B. bronchiseptica by whole-cell protein electrophoresis and fatty acid analysis. Int. J. Syst. Bacteriol. 45:843-847.

31. Vandamme, P., J. Hommez, M. Vancanneyt, M. Monsieurs, B. Hoste, B. Cookson, C. H. Wirsing von Konig, K. Kersters, and P. Blackall. 1995. Bordetella hinzii sp. nov., isolated from poultry and humans. Int. J. Syst. Bacteriol. 45:37-45.
32. Vandamme, P., M. Vancanneyt, B. Pot, L. Mels, B. Hoste, D. Dewettinck, L. Vlaes, C. Van Den Borre, R. Higgins, J. Hommez, K. Kersters, J.-P. Butzler, and H. Goossens. 1992. Polyphasic taxonomic study of the emended genus Arcobacter, with Arcobacter butzleri comb. nov. and Arcobacter skirrowii sp. nov., an aerotolerant bacterium isolated from veterinary specimens. Int. J. Syst. Bacteriol. 42:344-356.

33. Verhaegen, J. Personal communication.

34. Walc-Pokrzywnicki, Z. 1973. Flagella staining. Zentralbl. Bakteriol. Parasitenkd. Infektionskr. Hyg. Abt. 1 Orig. Reihe A 223:240-243.

35. Wayne, L. G., D. J. Brenner, R. R. Colwell, P. A. D. Grimont, P. Kandler, M. I. Krichevsky, L. H. Moore, W. E. C. Moore, R. G. E. Murray, E. Stackebrandt, M. P. Starr, and H. G. Trüper. 1987. Report of the Ad Hoc Committee on Reconciliation of Approaches to Bacterial Systematics. Int. J. Syst. Bacteriol. 37:463-464.

36. Weiss, A. A. 1992. The genus Bordetella, p. 2530-2543. In A. Balows, H. G. Trüper, M. Dworkin, W. Harder, and K.-H. Schleifer (ed.), The prokaryotes, 2nd ed., vol. 2. Springer-Verlag, Berlin.

37. Welch, D. F. 1991. Applications of cellular fatty acid analysis. Clin. Microbiol. Rev. 4:422-438.

38. Weyant, R. S., D. G. Hollis, R. E. Weaver, M. F. M. Amin, A. G. Steigerwalt S. P. O'Connor, A. M. Whitney, M. I. Daneshvar, C. W. Moss, and D. J. Brenner. 1995. Bordetella holmesii sp. nov,, a new gram-negative species associated with septicemia. J. Clin. Microbiol. 33:1-7.

39. Willems, A., J. De Ley, M. Gillis, and K. Kersters. 1991. Comamonadaceae, a new family encompassing the acidovorans rRNA complex, including Variovorax paradoxus gen. nov., comb. nov., for Alcaligenes paradoxus (Davis 1969). Int. J. Syst. Bacteriol. 41:445-450.

40. Wilson, M. J., W. G. Wade, and A. J. Weightman. 1995. Restriction fragment length polymorphism analysis of PCR-amplified $16 \mathrm{~S}$ ribosomal DNA of human Capnocytophaga. J. Appl. Bacteriol. 78:394-401.

41. Yabuuchi, E., and I. Yano. 1981. Achromobacter gen. nov. and Achromobacterxylosoxidans (ex Yabuuchi and Ohyama 1971) nom. rev. Int. J. Syst. Bacteriol. 31:477-478. 